\title{
Lise öğrencilerinin dikkat kontrolleri üzerinde etkili olan değişkenlerin CHAID analizi ile incelenmesi
}

\author{
Mehmet ŞATA $^{1}$ \\ 1 Ars.. Gör. Gazi Üniversitesi, Gazi Eğitim Fakültesi, Eğitim Bilimleri Bölümü, mehmetsata@gmail.com
}

DOI: http://dx.doi.org/10.14582/DUZGEF.747

$\mathrm{Bu}$ araștırmanın amacı, lise öğrencilerinin dikkat kontrollerini etkileyen faktörlerin neler olduklarının belirlenmesidir. Araştırmanın evrenini 2015-2016 eğitim öğretim yılında Batman İli Milli Eğitim Müdürlüğü’ne bağlı liselerde okuyan öğrenciler, örneklemini ise seçkisiz olmayan örnekleme yöntemlerinden uygun örnekleme yöntemi ile seçilen 700 kız ve 1124 erkek öğrenci olmak üzere toplam 1824 öğrenci oluşturmaktadır. Araştırmaya katılan lise öğrencilerinin dikkat kontrollerini belirlemek amacıyla, Fajkowska ve Derryberry (2010) tarafindan geliştirilen ve Akın ve diğerleri, (2013) tarafından Türkçe’ye uyarlama çalışması yapılan "Dikkat Kontrol Ölçeği” kullanılmıştır. Öğrencilerin sosyo-demografik bilgileri ise araştırmacı tarafından oluşturulan "Kişisel Bilgi Formu" aracığıyla toplanmıştır. Veri kümesinin analizinde SPSS 21.0 paket programı kullanılmıștır. Yapılan analizler sonucunda, lise öğrencilerinin dikkat kontrol mekanizmaları üzerinde etki düzeyi en yüksek değişkenin telefon kullanma sıklığ1 olduğu ve daha sonra sırasıyla cinsiyet, yaş ve aile ile birlikte yaşama durumlarının etkili oldukları bulunmuştur. Bu çalışma kapsamında elde edilen sonuçlara dayalı olarak, lise öğrencilerinin telefon kullanma sıklıklarının azaltılmasının faydalı olunacağı düşünülmektedir.

Anahtar Kelimeler: dikkat kontrolü, CHAID analizi, lise öğrencileri.

\section{Examining the variables effecting the controls attention of high school students Using CHAID Analysis}

\begin{abstract}
The purpose of this research, the factors affecting the controls attention of high school students to determine what happened. The population of research consists of the students studying at high schools bound to Batman Provincial Directorate of National Education in 2015-2016 educational year and the sample of this study consists of 700 female and 1124 male students (1824 in total) who were chosen by using convenience sampling that is one of methods of the non random sampling. In order to determine the controls attention of high school student, Attention Control Scale which was developed by Fajkowska and Derryberry (2010) and was conducted the Turkish adaptation study by Akın et al., (2013) were used. Personal Information Form, which was developed by the researcher to get students' sociodemographic information were collected. SPSS 21.0 packaged software was used for statistical analysis of the data. As a result of the analyses, which were CHAID analysis, the independent variables having the highest effect on high school students' controls attention were "the frequency of smartphone use" and then respectively gender, age and live with family. Based on the results obtained in this study, high school students are thought to be beneficial to reduce the frequency of use of the smartphone.
\end{abstract}

Keywords: attention control, CHAID analysis, high school students.

\section{GİRİ̧̧}

Dikkat, bireyin düşünce sisteminin belli bir süre bir uyarıcıya yönlendirilmesi ve bu sırada diğer uyarıcıların ihmal edilmesidir (Cammann \& Spiel, 1991, s.11). Yaycı (2007) dikkati, alg1lamadaki aktif ve seçici bir öğeye verilen isim olarak tanımlamaktadır. Ratey’e (2001) göre ise dikkat sadece uyarıcıları fark etmek değil aynı zamanda algıları filtreleme, farklı algıları karşılaştırma ve bu algılara duygusal anlam verme gibi bazı süreçlerden de oluşur. Selçuk \& Öztürk (1992) ise dikkatin, öğrenen kişinin öğrenilecek konu üzerinde yoğunluk kazanması olduğunu belirtmişlerdir. Ĕ̆itim ortamı dikkate alındığında, öğrenci merkezli yaklaşımda öğrencinin başarısız olmasına sebep olan faktörlerin belirlenmesi ve böylelikle ortaya çıkacak olumsuz sonuçlara zamanında müdahale edilmesi çok önemlidir. Bu bağlamda öğrenci başarısının ve dolaylı olarak da kişilik gelişimini etkileyen bir faktör olarak “dikkat ve “dikkat kontrolü” kavramları önem arz etmektedir. 
Dikkat, alg1, bellek gibi bilişsel özellikler öğrenme süreci içinde kalıcı öğrenme açısından oldukça önemlidir (Salthouse, Berish \& Miles, 2002). Bir öğretim programında, öğrenenlerin (öğrenciler) yetenek ve becerileri gibi bilişsel özellikleri ile ilgili olarak bilgi toplanmalıdır. Bilişsel özellikler öğrenme ortamlarında en fazla dikkate alınan özellikler olarak öğretim tasarımlarına da yansıtılmalıdır (Akkoyunlu, Altun \& Yılmaz, 2011). Çünkü dikkatin öğrenme süreci için bir ön koşul olduğu bilinmekte (Demir, 2009, s.139) ve dikkat kontrol becerisi ve dikkatin sürekliliği akademik başarı için gerekli olan bilişsel kriterler arasında yer almaktadır (Ruf \& Arthen, 2006, s. 35). Önemli olmayan bilgi kaynağının önemli olan bilgi kaynağından ayırt edebilmek ve önemli bilgi kaynağı üzerinde yoğunlaşarak öğrenme görevini gerçekleştirebilmek dikkatli bir öğrencinin özellikleridir (Sünbül \& Çelik, 1998, s. 437). Yeterli bir dikkat düzeyine sahip bir öğrenci ile dikkatsiz veya yetersiz düzeyde dikkate sahip olan öğrencilerin öğrenme düzeylerinin birbirinden farklı olduğu bilinmektedir (Sünbül \& Çelik, 1998, s. 438).

Dikkati bir şeye odaklama sürecinde dikkat üzerinde dağıtıcı etkiye sahip diğer faktörleri kontrol etme yeteneği, bireyin davranışlarını etkili bir biçimde düzenlediğinin bir göstergesidir. Dikkat kontrolü ise bireyin görevine odaklanmasını, içsel ve dışsal dikkat dağıtıcı faktörleri kontrol altına almasını ya da bunlara karşı konulmasını ve önceden belirlediği amaçlara ulaşma çabasını kapsamaktadır (Luszczynska, Diehl, GutiérrezDoña, Kuusinen \& Schwarzer, 2004). Dikkat kontrolü üzerine yapılan araştırmalara bakıldığında, dikkat kontrolü yüksek olan bireylerin belirledikleri hedefler üzerinde çalışma konusunda daha fazla kararlı oldukları ve amaçlarına ulaşmak için daha fazla zaman ve emek harcadıkları tespit edilmiştir (Diehl, Semegon \& Schwarzer, 2006). Başka bir araştırmada (Stanescu \& Iorga, 2015) ise dikkat kontrol düzeyleri düşük bireylerin amaçlarına uluşma konusunda düşük bir performansa sahip oldukları ve sabırlı olmak yerine anlık doyum sağlayan etkinlikleri tercih ettikleri belirlenmiştir. Dikkat kontrol mekanizmasının akademik özyeterlik ve genel özyeterlik ile ilişkisine bakılan bir araştırmada (Prasad, Lim \& Chen, 2010) anlamlı pozitif bir ilişkinin bulunduğu belirlenmiş ve dikkat kontrol mekanizmasının akademik performansın anlamlı bir yordayıcısı olduğu sonucuna varılmıştır.

Dünya Sağlık Örgütü'nün (DSÖ) genç bireylerin (18 yaş altı) teknoloji kullanımları ile ilgili yaptıkları çalışma sonucu yayınladıkları rapora göre genç bireylerin çok fazla teknoloji araçlarını kullandıkları ve bunun bu yaşlarda sakıncalı olduğu belirtilmiştir (World Health Organization, 2002). Lise öğrencilerinin önceki (ortaokul) ve sonraki (üniversite) eğitim dönemlerine göre lise yıllarında daha fazla dikkat dağınıklığı yaşadığı bunun birçok temel nedeni olduğu alanyazında belirtilmiştir. DSÖ'nün (2002) araştırmasına göre, lise öğrencilerin dikkat mekanizmalarını etkileyen değisskenlerin neler olduğu önem arz etmektedir. Dolaysıyla ilgili çalışma kapsamında dikkati etkileyen değişkenlerden bir kısmının CHAID analizi (değişkenler arası ilişkileri ortaya koymada etkili bir yöntem) ile ele alınması önemli görülmüştür.

$\mathrm{Bu}$ bağlamda bireylerin dikkat kontrol mekanizmalarının hangi düzeyde olduğu ve bu mekanizma üzerinde hangi değişkenlerin etkili olduğu önem arz etmektedir. Özellikle okul çağındaki bireylerin etkili ve verimli bir biçimde öğretim programının belirlediği amaçlara ulaşmak için yüksek bir dikkat kontrolüne sahip olmaları gerektiği alanyazında belirtilmiştir. Bu kapsamda lise öğrencilerinin dikkat kontrol mekanizmaları üzerinde etkili olan değişkenleri tespit etmek bu çalışmanın temel amacını oluşturmaktadır. Bu temel amaç doğrultusunda şu sorulara yanıt aranmıştır:

1. Lise öğrencilerinin dikkat kontrolleri üzerinde etkili olan değişkenler nelerdir?

2. Lise öğrencilerinin dikkat kontrolleri üzerinde etkili olan değişkenlerin ilişki düzeyleri ve etki büyüklükleri nasıldır?

\section{YÖNTEM}

\subsection{Araştırmanın Deseni}

$\mathrm{Bu}$ araştırma, lise öğrencilerinin dikkat kontrol mekanizmasının hangi düzeyde olduğu ve dikkat kontrol mekanizması üzerinde hangi değişkenlerin etkili olduğunu belirlemeye yönelik olduğundan araştırmada betimsel yöntemlerden ilişkisel tarama deseni kullanılmıştır (Büyüköztürk, Çakmak, Akgün, Karadeniz \& Demirel, 2013). İlişkisel tarama araştırmaları, iki veya ikiden daha çok sayıda olan değişkenlerin arasında birlikte değişimin varlığını belirlemeye yönelik olan araştırma modelleridir (Karasar, 2014). 


\subsection{Evren ve Örneklem}

Çalışmanın evrenini 2015-2016 eğitim öğretim yılında Batman İli Milli Eğitim Müdürlüğüne bağlı liselerde öğrenim gören toplam 35500 öğrenci oluşturmaktadır. Örneklemini ise İluh Anadolu Lisesinden 914, (311 k1z ve 603 erkek) Mehmet Akif Ersoy Anadolu Lisesinden 910 ( 389 k1z ve 521 erkek) öğrenci olmak üzere toplam 1824 öğrenci oluşturmaktadır. Öreneklem, seçkisiz olmayan örnekleme yöntemlerinden uygun örnekleme yöntemi ile seçilmiştir. Çalışma kapsamında ele alınan örnekleme ilişkin demografik bilgiler Tablo 1 'de verilmiştir.

Tablo 1. Öğrencilere ait değişkenlerin frekans ve yüzdeleri

\begin{tabular}{|c|c|c|c|}
\hline Değişkenler & Değişken Düzeyleri & Frekans (f) & Yüzde (\%) \\
\hline \multirow{7}{*}{ Yaş } & 14 & 44 & 2.4 \\
\hline & 15 & 588 & 32.2 \\
\hline & 16 & 176 & 9.6 \\
\hline & 17 & 428 & 23.5 \\
\hline & 18 & 492 & 27.0 \\
\hline & 19 & 92 & 5.0 \\
\hline & 20 & 4 & 0.2 \\
\hline \multirow[b]{2}{*}{ Cinsiyet } & $K_{1 z}$ & 700 & 38.4 \\
\hline & Erkek & 1124 & 61.6 \\
\hline \multirow{4}{*}{ Aile ile birlikte olma durumu } & Anne ve baba ile birlikte & 1648 & 90.4 \\
\hline & Anne ile birlikte & 140 & 7.7 \\
\hline & Baba ile birlikte & 28 & 1.5 \\
\hline & Anne ve baba ile birlikte değil & 8 & 0.4 \\
\hline \multirow{4}{*}{ Ailenin aylık geliri } & $1.500 \mathrm{TL}$ ve altı & 592 & 32.5 \\
\hline & 1.501 TL-3.000 TL aras 1 & 964 & 52.9 \\
\hline & 3.001-5.000 TL aras1 & 188 & 10.3 \\
\hline & 5.001 TL ve üstü & 80 & 4.4 \\
\hline \multirow{4}{*}{ Telefon kullanma sıklığ1 } & $\mathrm{Az}$ & 392 & 21.5 \\
\hline & Orta & 276 & 15.1 \\
\hline & Çok & 1156 & 63.4 \\
\hline & Toplam & 1824 & 100 \\
\hline
\end{tabular}

\subsection{Veri Toplama Arac1}

Bu araştırmada Fajkowska \& Derryberry (2010) tarafından geliştirilen ve Akın ve diğerleri, (2013) tarafindan Türkçe'ye uyarlama çalışması yapılan "Dikkat Kontrol Ölçeği” veri toplama aracı olarak kullanılmıştır. Ölçek uygulanmadan önce araştırmacılardan gerekli izin alınmıştır. Ayrıca araştırmanın amacına uygun olacak şekilde araştırmacı tarafindan tasarlanan "Kişisel Bilgi Formu" kullanılarak araştırma için demografik bilgiler toplanmıştır. Ölçek 20 maddeden oluşmaktadır. Maddeler olumsuzdan olumluya doğru dörtlü likert dereceleme ile ölçeklendirilmiştir. Ölçekten alınabilecek puanlar 20 ile 80 arasında değişmektedir. Kendini değerlendirme ölçek tipidir. Ölçekten alınacak olan toplam puanın yüksek olması öğrencilerin dikkat kontrol düzeylerinin yüksek olduğunu, toplam puanın düşük olması ise öğrencilerin dikkat kontrol düzeylerinin düşük olduğunu göstermektedir.

Ölçeğin psikometrik özelliklerine bakıldığında, Ölçeğin madde ayırt ediciliği için madde-toplam korelasyonları hesaplanmış ve .28 ile .45 arasında sıralandı̆̆ı bulunmuştur. Yap1 geçerliği için doğrulayıcı faktör analizi (DFA) uygulanmıştır. DFA sonucunda tek boyutlu modelin yeterli uyum sağladığ1 görülmüştür $(\chi 2=$ 426.76, $\mathrm{sd}=164, \chi 2 / \mathrm{sd}=2.60, \mathrm{RMSEA}=.062, \mathrm{IFI}=.81, \mathrm{CFI}=.80, \mathrm{GFI}=.91, \mathrm{AGFI}=.88, \mathrm{SRMR}=.067)$. Cronbach alfa iç tutarlık güvenirlik katsayısı ölçeğin bütünü için .78 olarak bulunmuştur (Akın ve diğerleri, 2013). Mevcut çalışmada ölçme aracı farklı özelliklere sahip bir örnekleme uygulandı̆̆1 için geçerlik ve güvenirlik çalışması yeniden yapılmış olup aşağıda verilmiştir.

Ölçek geliştirenlerin güvenirlik ve geçerlik çalışmaları yapması ve ölçeği uygulayanların da uygulayacakları ölçeğin güvenirlik ve geçerlik çalışmasının yapılıp yapılmadığını sorgulamalıdır. Eğer ölçeğin güvenirlik ve geçerliğin incelendiği örneklem ile sonradan ölçeğin uygulanması düşünülen örneklem arasında önemli farklılıklar varsa ölçeğin güvenirlik ve geçerliğinin tekrar sorgulanması gerekmektedir (Ercan \& Kan, 2004). Yapılan araştırmada seçilen örneklemin ölçek uyarlama çalışmasında kullanılan örneklemden farklı olması dikkate alındığında Dikkat Kontrol Ölçeği’nin (DKO) yeniden güvenirlik ve geçerlik çalışmasının gerekli olduğu görülmüştür. 
Araştırma kapsamında kullanılan ölçeğin, uyarlanmış formunda bulunan 20 madde lise öğrencilere uygulanmış ve elde edilen sonuçlar puanlandıktan sonra, geçerlik ve güvenirlik analizi yapılmıştır. Toplanan verilerin faktör analizine uygunluğunun Kaiser-Meyer-Olkin (KMO) ve Barlett testi ile sinanmıştır (Büyüköztürk, 2013). Tablo 2'de KMO ve Barlett küresellik testine ilişkin elde edilen değerler verilmiştir.

Tablo 2. KMO ve Barlett Küresellik Testi Değerleri

Kaiser-Meyer-Olkin (KMO)

Barlett küresellik (Sphericity) testi

$\begin{array}{ll}\text { Ki-Kare } & .912 \\ \text { Serbestlik Derecesi (sd) } & 13474,475 \\ p & 190 \\ & .000\end{array}$

Tablo 2'de görüldüğü gibi yapılan test sonucu Kaiser-Mayer-Olkin (KMO) değeri .912 ve Barlett küresellik testi; $\chi^{2}$ değeri ise $13474,475(\mathrm{p}<$.000) olarak anlamlı düzeyde olduğu bulunmuş ve seçilen örneklem büyüklügünün uygunluğu test edilmiştir. KMO değerinin 0,60’tan yüksek olması ve Barlett testinin anlamlı çıkması verinin faktör analizine uygun olduğunun göstergesidir (Büyüköztürk, 2013).

Verilerin çok değişkenli normal dağglımlarını test etmek ve uç değerleri tespit etmek için Mahalonobis ve Leverage değerlerine bakılmıştır. Veri setinin çok değişkenli normal dağılım sergilemediği ve uç değer olmadığ1 görülmüştür. Değişkenler arasında doğrusal ilişkinin kontrolü için ZPRED-ZRESID saçılma diyagramına bakılmış ve gerekli koşulları sağladığı görülmüştür. Maddeler arası basit korelasyona bakılmış ve ,80'den büyük değer olmadığı, dolayısıyla çoklu doğrusal bağlantı sorunu bulunmadığı tespit edilmiştir. Tüm bu sayıltıların sağlanmasından sonra faktör analizine geçilmiştir.

Doğrulayıcı faktör analizi (DFA) yapı için ölçümlerin geçerliğinin bir kanıtı olarak gösterildiğinden uygulaması yapılan ölçeğin orjinalinde tanımlanan tek faktörlü ölçme modeli oluşturularak doğrulayıcı faktör analizi (LISREL 8.80 programında) yapılmıştır. Bu araştırmada söz konusu ölçümlerin yapı geçerliğine ilişkin kanıt olarak, "ölçme modelindeki göstergelerin (maddelerin) ilgili yapının iyi birer temsilcileri olmaları" ve “ölçme modellerinin veriye yeterli düzeyde uyum sergilemesi” ölçütleri ele alınmıştır. Ölçme modelinin veriye yeterli düzeyde uyum sergilediğinin kabul edilebilmesi için, $\mathrm{GFI} \geq 0,90, \mathrm{CFI} \geq 0,90$ ve $\mathrm{RMSEA} \leq 0,08$ olması koşulları dikkate alınmıştır (Brown, 2015).

Tablo 3. Dikkat Kontrol Ölçeğinin Faktör Yapısına Yönelik Test Edilen Ölçme Modeline İlişkin Hesaplanan Uyum İndeksleri

\begin{tabular}{lccccc}
\hline Model & GFI & AGFI & CFI & NNFI & RMSEA \\
\hline Değerler & 0.88 & 0.85 & 0.95 & 0.94 & 0.079 \\
\hline
\end{tabular}

Uyum indekslerinden GFI ve AGFI genelde >.90 ölçütünü sağması gerekmektedir. Ancak bu değerler çok değişkenli normallik varsayımının ihlalinden çok fazla etkilenmektedirler. Verilerin çok değişkenli normal dağılım varsayımını sağlamadığı durumlarda GFI ve AGFI değerleri yerine NNFI ve CFI değerleri esas alınır. İlgili veri setinde çok değişkenli normal dağılım sayıltısı sağlanmadığından GFI ve AGFI değerleri yerine NNFI ve CFI değerleri temel alınmıştır. Sonuç olarak NNFI=.94, CFI=.95 >.90 değerleri modelin uyumlu olduğunu ortaya koymaktadır. Gerçekleştirilen analizler sonucunda, modelin veri ile kabul edilebilir bir uyum sağladığı söylenebilir. Ölçme modeline ilişkin standartlaştırılmış çözümleri ve maddelerin yük değerleri Şekil 1 'de sunulmuştur. 


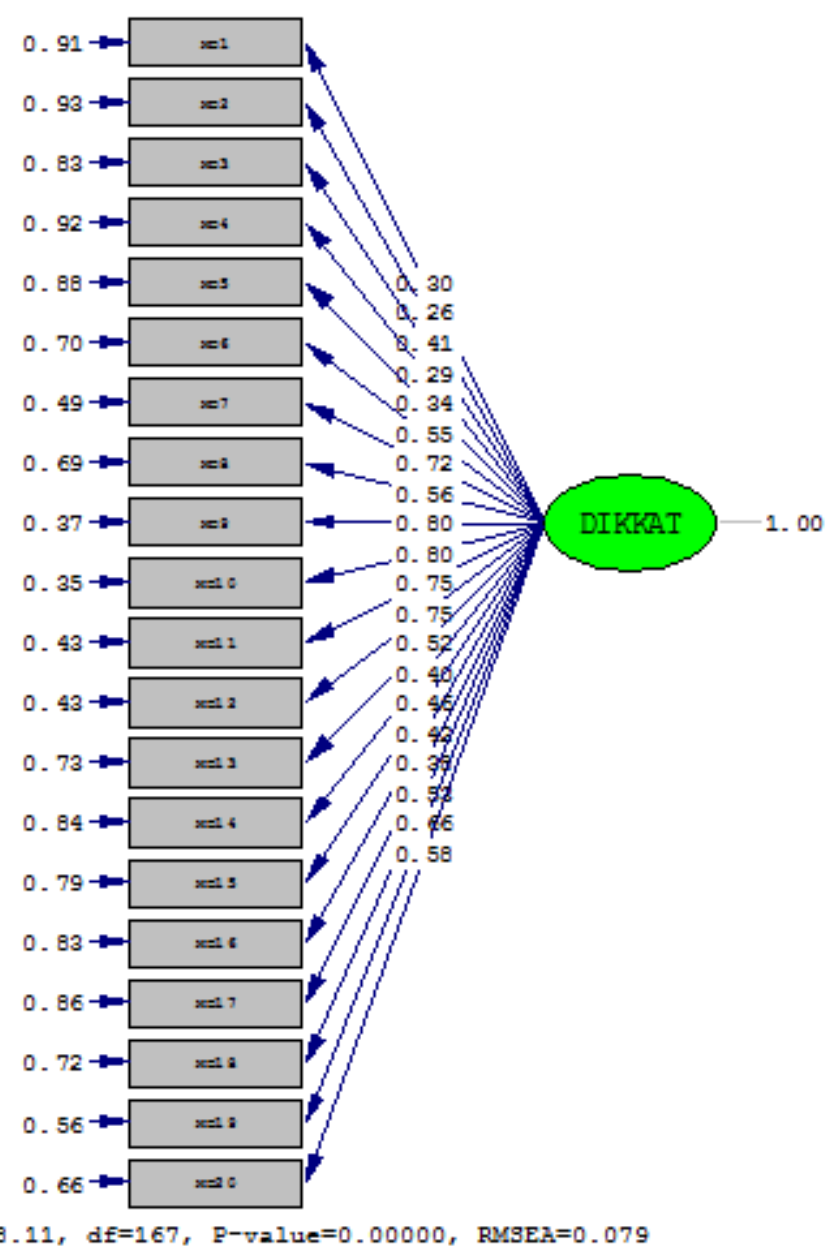

Şekil 1. Dikkat kontrol ölçeğinin faktör yapısına ilişkin tanımlanan ölçme modeli (standartlaştırılmış ağırlıklar)

Şekil 1'de gösterilen faktör yük değerleri ve hata değerleri, ilgili maddelerin ilgili faktörlerin iyi/uygun birer temsilcileri olduklarına ve kabul edilebilir düzeyde hata içerdiklerine işaret etmektedir. Ölçme modeline dayalı olarak göstergelere ilişkin hesaplanan faktör yük değerlerinin $(\lambda=0.35-0.93)$ ve hata değerlerinin $(\varepsilon=0.26$ 0.80) oldukları görülmektedir. Tüm bu bulgular, ölçme modelinin ilgili veriye iyi ve yeterli düzeyde uyum sergilediğini ve modelde yer alan göstergelerin ilgili yapıları daha iyi temsil ettiklerini göstermektedir. Bu bulgular ölçeğin 20 maddelik formunun, lise öğrencileri için, ölçmeyi amaçladığ1 yapıyı geçerli bir şekilde ölçebildiğine işaret etmektedir.

\subsection{Veri Analizi}

Veri analizinde, ölçekten elde edilen toplam sürekli puanını kategorik puanlara dönüştürmede kullanılan iki aşamalı kümeleme analizi ve bağımlı değişken ile bağımsız değişkenler arasında doğru ve yansız sınıflandırma yapan CHAID analizi kullanılmıştır. Analizler için SPSS 21 ve LISREL 8.80 paket programları kullanılmıştır.

\subsection{1. İki Aşamalı Kümeleme Analizi}

Ölçekten elde edilen toplam puan sürekli bir değişken olduğundan sınıflandırma yöntemlerinden biri olan iki aşamalı kümeleme analizi kullanılarak ölçeğin toplam puanı yüksek düzey ve düşük düzey olmak üzere kategorik iki küme haline getirilmiştir. Ölçeğin toplam sürekli puanının kategorik puana dönüştürülmesinin temel sebebi, CHAID analizinin kategorik verilerde daha iyi sonuç vermesi gösterilmektedir (Pehlivan, 2006). Ayrıca örnekleme alınan öğrencilerin aynı evrenden gelmeme olasılığı dikkate alınarak, veri seti daha homojen alt gruplara ayrilmıstır.

Kümeleme analizi temel olarak nesneleri sahip oldukları karakteristik özelliklerine göre gruplara ayırmayı hedefleyen çok değişkenli bir istatistiksel tekniktir (Çokluk, Şekercioğlu \& Büyüköztürk, 2012). İki Aşamalı Kümeleme Analizi veri setinin homojen alt gruplara ayırmasını sağlamaktadır. Homojen olmayan veri setinin homojen alt gruplara ya da kümelere bölünmesinden sonra elde edilen istatistiksel çalışmaların daha sağlıklı sonuçlara sahip olduğu alan yazında bildirilmektedir (Kayri, 2007). Kümeleme analizi, seçilen özellikler açısından birbirlerine diğerlerinden daha çok benzeyen bireyleri ya da objeleri bir kümede toplar. Eğer yapılan 
kümeleme işlemi başarılı ise, geometrik gösterimde küme içinde yer alan nesneler birbirine yakın iken, farklı kümelerde yer alan nesneler birbirinden uzak olacaklardır (Hair, Black, Babin \& Anderson, 2010).

\subsubsection{CHAID Analizi}

Lise öğrencilerinin dikkat kontrol düzeylerinin ne olduğu ve bu düzey üzerinde hangi değişkenlerin etkili olduğunu belirlemek amacıyla veri madenciliğinde kullanılan karar ağaçları yöntemlerinden CHAID analizi kullanılmıştır. Bu çalışmada CHAID analizinin tercih edilme sebepleri olarak; uygulanan ölçekten elde edilen toplam puan dağılımının normal dağılım sağlamaması, CHAID analizinin kategorik verilerde çok güçlü olması ve bağımlı değişken ile bağımsız değişkenler arasındaki ortak etkiyi ortaya çıkarması gösterilebilir. Ayrıca kuramdan daha çok uygulamada baskın olan eğitim bilimleri gibi alanlarda değişkenler arası ilişkiyi daha detaylı ve anlaşılır kılmak için bu çok değişkenli analizlerinin kullanılması önemli görülmektedir.

CHAID analizi, veri madenciliğinde yaygın olarak kullanılan karar ağaçları yöntemlerinden biridir. CHAID (Ki-Kare Otomatik Etkileşim Detektörü) analizi Kass (1980) tarafından ortaya atılmıştır. Bu analizde Ki-kare olmasının nedeni, algoritmasında birçok çapraz tablonun bulunması ve istatistiksel anlamlılık oranları ile çalışmasıdır. Ağaç diyagramı çizilirken, en önemli ilişkiler seçilerek yapilır (Hoare, 2004). CHAID analizi, bağımlı değişkeni en iyi yordayabilecek biçimde ayrıntılı homojen alt gruplara böler. Bu araştırmada CHAID analizinin kullanılmasının sebep ve gerekçeleri şöyle sıralanabilir (Üngüren \& Doğan, 2010):

- Sürekli ve kategorik veri aynı anda ölçme modeline dâhil edilebilmektedir.

- Bağımlı ve bağımsız değişkenler arasındaki ilişkiler daha detaylı değerlendirilebilmektedir.

- Bağımlı değişkenler üzerinde etkili olan bağımsız değişkenler bir ağaç diyagramı üzerinde resmedilerek gösterebilmektedir.

- Ağaç diyagramı diğer analiz sonuçlarına göre görsel anlamda daha kolay bir biçimde yorumlanabilmektedir.

- Elde edilen analiz sonuçlarının anlaşılma düzeyini kolaylaştırmaktadır.

\section{BULGULAR}

\subsection{Birinci Araştırma Sorusuna İlişkin Bulgular}

Bu bölümde "Lise öğrencilerinin dikkat kontrolleri üzerinde etkili olan değişkenler nelerdir?” birinci araştırma sorusunu cevaplamak amacıyla CHAID analizi sonucunda elde edilen bulgulara yer verilmiştir. Araştırma kapsamında ele alınan veri seti için kurulan regresyon modelinde, bağımlı değişken ölçekten elde edilen toplam puanın kategorikleştirilmişşekli (yüksek kontrol/düşük kontrol), bağımsız değişkenler ise lise öğrencilerinin cinsiyetleri, yaşları, aileleri ile birlikte yaşama durumları, ailenin aylık geliri ve öğrencinin telefon (akıllı telefon) kullanma durumları modele alınmıştır.

Şekil 2, lise öğrencilerinin dikkat kontrolleri üzerinde etkili olan faktörlerin (değişkenlerin) CHAID analizi ile incelenmesini göstermektedir. Lise öğrencilerinin dikkat kontrolleri üzerinde etkili olan bağımsız değişkenleri belirlemek amacıyla yapılan CHAID analizi sonucunda, öğrencilerin dikkat kontrolleri üzerinde etki düzeyi en yüksek değişkenin "telefon kullanma sılklı̆̆" olduğu görülmektedir ( $\chi 2=200.28$; $p=0.000)$. Telefon kullanma sıklığ1 artıkça öğrencilerin dikkat kontrol düzeylerinin azaldığ1 görülmektedir. Telefon kullanma sıklığı bağımsız değişkeni için ortak etkinin olup olmadığına bakılmış ve bağımsız değişkenin düzeyleri arasında disordinal ortak etkinin olduğu görülmüştür. Bu sonuca göre telefon kullanma sılklı̆ı değişkeninin üç düzeyinin etkisi dikkat kontrol mekanizmasının iki düzeyinde aynı değildir. 


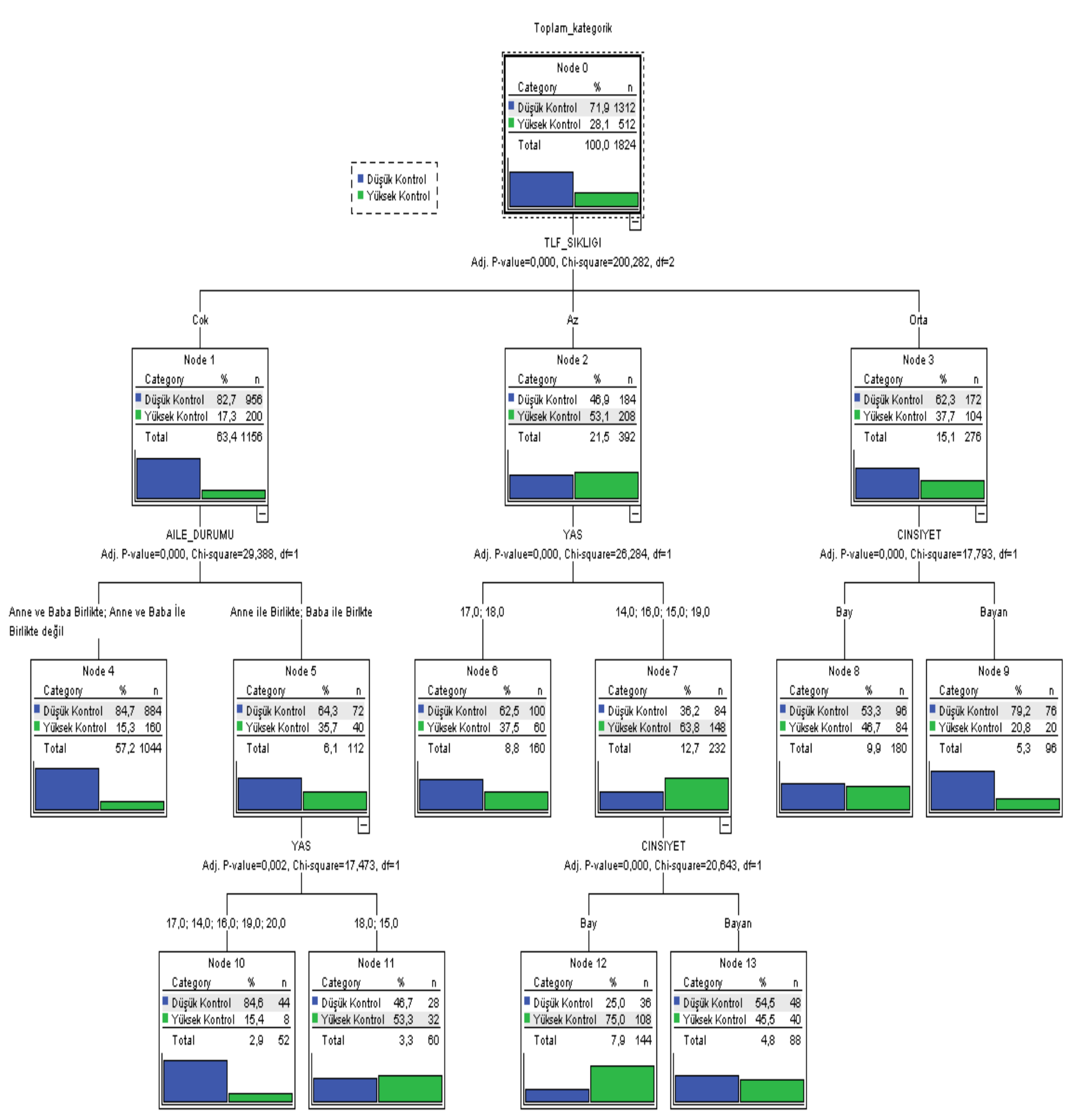

Şekil 2. Dikkat kontrolü üzerinde etkili olan değişkenlere ilişkin CHAID analizi

Telefon kullanma sıklı̆̆1 az olan öğrencilerin bu durumları üzerindeki en etkili değişken öğrencilerin yaş durumu olduğu belirlenmiştir $\left(\chi^{2}=26.294 ; p=0.000\right)$. Şekil 2 incelendiğinde, 17 ve 18 yaşlarındaki öğrenciler 14, 15, 16 ve 19 yaşlarındaki öğrencilerden daha düşük bir dikkat kontrol düzeyine sahip oldukları görülmektedir. Öğrencilerin yaş durumları bağımsız değişkeni için ortak etkinin olup olmadığının belirlenmesi amacıyla ortak etki grafiği çizilmiş ve sıralı olmayan ortak etki olduğu bulunmuştur. Bu sonuca göre yaş bağımsız değişkenin düzeylerinin etkisi telefon kullanma sıklığı değişkenin üç düzeyinde farklıdır. Telefon kullanma sıklığı orta düzeyde olan öğrencilerin bu durumları üzerindeki en etkili değişken öğrencilerin cinsiyet durumu olduğu tespit edilmiştir ( $\chi^{2}=17.793$; $p=0.000$ ). Şekil 2'de cinsiyet değişkeni incelendiğinde, telefonu orta düzeyde kullanan erkek öğrencilerin kız öğrencilere göre daha yüksek bir dikkat kontrol düzeyine sahip oldukları görülmektedir. Çok fazla telefon kullanan öğrencilerin bu durumları üzerindeki en etkili değişken öğrencilerin aileleri ile birlikte yaşama durumu olduğu bulunmuştur $\left(\chi^{2}=29.388 ; p=0.000\right)$. Ortak etki grafiği çizildiğinde sıralı olmayan ortak etkinin olduğu tespit edilmiştir. Anne ve babası ile birlikte yaşayanlar ile anne ve babası birlikte yaşamayan öğrencilerin anne veya babasından birinin yanında yaşayan öğrencilere göre daha düşük dikkat kontrol düzeyine sahip oldukları belirlenmiştir. 


\section{2. İkinci Araştırma Sorusuna İlişkin Bulgular}

Bu bölümde "Lise öğrencilerinin dikkat kontrolleri üzerinde etkili olan değişkenlerin ilişki düzeyleri ve etki büyüklükleri nasıldır?” araştırma sorusunu cevaplamak amacıyla değişkenler arasındaki ilişki kestirimi için Contingency katsayısı (C) ve etki büyüklüğü için ise Cohen (1988) tarafından tanımlanan etki büyüklüğü katsayısı kullanılmıştır. Bu istatistikler aşağıda verildiği gibidir. CHAID analizinde bağımlı değişken kategorik olduğu durumda ki-kare istatistiği kullanılmaktadır. Ki-kare istatistiğinde anlamlı bulunan bağımsız değişkenler için bağımlı değişken ile bağımsız değişken arasındaki ilişki derecesi ve anlamlı değişkenin etki büyüklüğünün hesaplanmasi gerekir.

$$
C=\sqrt{\chi^{2} / \chi^{2}+N}
$$

Contingency katsayısı normal korelasyon katsayısı gibi yorumlanır.

$$
\mathrm{d}=\left(\chi^{2} / \mathrm{N}\right)^{1 / 2}
$$

$\mathrm{Bu}$ istatistik araştırmacıların yargı kurmasına yardımcı olmaktadır (Kirk, 2008). Cohen'e göre (1988) etki büyüklüğünün yorumlanması şu şekilde yapılmaktadır;

$$
\begin{aligned}
& \mathrm{d}=.10-.29 \text { ise küçük etkiye } \\
& \mathrm{d}=.30-.49 \text { ise orta etkiye } \\
& \mathrm{d}=.50-1.00 \text { ise büyük etkiye sahip olduğu yorumu yapılmaktadır. }
\end{aligned}
$$

CHAID analizi sonucunda anlamlı bulunan değişkenlerin etki büyüklükleri ve ilişki dereceleri hesaplanmış ve Tablo 4'de verilmiştir.

Tablo 4. Anlamlı bulunan değişkenlerin etki büyüklükleri ve ilişki dereceleri

\begin{tabular}{lcc}
\hline Değişkenler & Etki Büyüklüğü (d) & İlişki Derecesi (C) \\
\hline Telefon kullanma sıklı̆̆1 & .33 & .32 \\
\hline Ailesi ile birlikte yaşama durumu & .16 & .16 \\
\hline Öğrencinin yaş1 & .26 & .25 \\
\hline Öğrencinin cinsiyeti & .25 & .25 \\
\hline
\end{tabular}

Tablo 4 incelendiğinde, telefon kullanma sıklığı bağımsız değişkeni için ilişki derecesi 32 ve etki büyüklüğü ise .33 olarak bulunmuştur. Bu sonuca göre telefon kullanma sıklığı bağımsız değişkeninin orta düzeyde bir ilişkiye ve etki büyüklügüne sahip olduğu söylenebilir. Öğrencinin ailesi ile birlikte yaşama değişkeni için ilişki derecesi 16 ve etki büyüklüğü ise .16 olarak hesaplanmıştır. Bu sonuca göre aile ile birlikte olma bağımsız değişkenin bağımlı değişken üzerinde küçük ilişki derecesine ve küçük etki büyüklüğüne sahip olduğu savunulabilir. Anlamlı bulunan diğer bir değişken olan öğrencilerin yaş durumu için ilişki derecesi .25 ve etki büyüklüğü de .26 olarak bulunmuştur. Bu sonuca göre öğrencilerin yaşı bağımsız değişkenin küçük ilişki derecesine ve etki büyüklüğüne sahip olduğu söylenebilir. Anlamlı olan son bağımsız değişkenimiz olan cinsiyet durumu için etki büyüklüğü ve ilişki derecesi .25 olarak bulunduğundan bu bağımsız değişkenin bağımlı değişken üzerinde zayıf bir ilişkiye ve küçük bir etki büyüklügüne sahip olduğu ifade edilebilir.

\section{TARTIŞMA, SONUÇ VE ÖNERİLER}

Bir öğretim programında, öğrencilerin yetenek ve becerileri gibi bilişsel özellikleri ile ilgili olarak bilgi toplanmalıdır. Alanyazın incelendiğinde en fazla dikkate alınan özelliklerin bilişsel özellikler olduğu görülmektedir. Bu özelliklerden biri olan dikkat kontrolü için bir çok çalışma yapıldığı görülmektedir ( Sünbül \& Çelik, 1998, s. 437; Ruf \& Arthen, 2006, s. 35; Küçük Doğaroğlu, 2013). Öğrencilerin dikkat kontrol düzeylerinin düşük veya yüksek olmasının sosyal hayatta, öğrenim sürecinde ve mesleki alanda başarısını aynı paralellikte etkileyeceği düşünülmektedir (Öztürk, Bayraktar, Öztürk \&Tozoğlu, 2016). Bu durumda öğrencilerin dikkat kontrol düzeylerini artırmada önemli olan unsurların belirlenmesi önem teşkil etmektedir. İlgili çalışma kapsamında lise öğrencilerinin dikkat kontrollerinin üzerinde etkili olan değişkenlerin neler olduğu ve bu değişkenlerin ilişki düzeyleri ile etki büyüklerinin ne oldukları araştırılmıştır. Elde edilen bulgulara dayanarak şu sonuçlara ulaşılmıştır.

\subsection{Birinci Araştırma Sorusuna İlişkin Sonuçlar}

Araştırmanın temel amacını taşıyan lise öğrencilerinin dikkat kontrolleri üzerinde etkili olan faktörlerin belirlenmesi için yapılan CHAID analizi neticesinde en etkili değişkenin "telefon kullanma sıklığı” olduğu 
belirlenmiştir. Telefon kullanım sıklığı artıkça lise öğrencilerinin dikkat kontrollerinin azaldığı bulunmuştur. Benzer sonuçlar Özcebe, Aydın, Daştan, Fırat \& Karaaslan (2013); Deveci, Açık, Gülbayrak, Demir, Karadağ \& Koçdemir (2007); Pala (2002) tarafindan da tespit edilmiştir. Bu bağlamda ulaşılan sonuçların alanyazın ile uyum içerisinde olduğu söylenebilir. Alanyazında mevcut olan diğer bir çalışmada ise aşırı telefon kullanan öğrencilerin sınavda sorulara daha hızlı yanıt verdikleri fakat daha fazla hata yaptıkları belirlenmiştir (Abramson, Benke, Dimitriadis, Inyang, Sim, \& Wolfe, 2009). İlhan (2008) tarafindan 18 ile 29 yaş aralı̆̆ındaki 287 kişinin telefon kullanımlarını incelediği çalışmada araştırma grubundaki bireylerin hepsinin telefona sahip olduğu ve hayatlarında vazgeçemeyecekleri bir yere sahip olduğunu belirtmişlerdir. Buradan hareketle genç bireyler için telefonun önemli bir yere sahip olduğu söylenebilir. Dünya Sağllk Örgütü’nün (DSÖ) cep telefonları hakkında yayınladığı raporda genç yaşlarda cep telefonu kullanmaya başlamanın daha sakıncalı olduğu belirtilmektedir. Büyüme ve gelişmenin devam ettiği yaşlarda, radyasyonun sağlık üzerine daha ciddi etkileri olabileceği düşünülmektedir. Bu nedenle 18 yaşın altındaki çocukların cep telefonu kullanımının kesinlikle önlenmesi gerektiğinden bahsedilmektedir (World Health Organization, 2002). Elde edilen bulgulara göre öğrencilerin telefon kullanma sıklığının dikkat kontrolü üzerindeki etkisi dikkate alındığında Dünya Sağlık Örgütü’nün önerdiği tedbirlerin alınması faydalı görünmektedir.

Telefon kullanma sıklı̆g üzerinde etkili olan değisskenlere bakıldığında, çok fazla telefon kullanan öğrencilerin bu davranışları üzerinde etkili olan değişken öğrencinin ebeveynleri ile yaşama durumu olduğu tespit edilmiştir. Anne ve babası ile birlikte yaşayan ile anne ve babası ile birlikte yaşamayan öğrencilerin, sadece annesi veya babası ile yaşayan öğrencilere göre daha düşük bir dikkat kontrol mekanizmasına sahip oldukları belirlenmiştir. Mathis \& Bierman (2012) tarafindan yapılan bir araştırmada; ebeveynliğin üç yönünün (ebeveyn stresi, ebeveyn-çocuk ilişkisinin kalitesi, öğrenme için ebeveyn desteği) her birinin, anaokulu yllı sırasında duygu düzenlemesi ve dikkat kontrolünün gelişimi ile anlamlı derecede ilişkili olduğunu belirtmişlerdir. Özellikle ebeveynlik rolündeki sıkıntı, çocuğun dikkat kontrolüyle anlamlı bir şekilde ters orantılı olarak ilişkili olduğu belirtilmiştir. Bu bağlamda ilgili çalışma kapsamındaki bireylerin ebeveynlerinden dolayı da bir dikkat kontol eksikliği yaşadığı söylenebilir. Telefon kullanma sıklığ1 az olan öğrencilerin bu davranışları üzerinde etkili olan değişkenin öğrencilerin yaş durumu olduğu tespit edilmiştir. 17 ve 18 yaşındaki öğrencilerin dikkat kontrolleri 14, 15, 16 ve 19 yaşındaki öğrencilere göre daha düşük olduğu bulunmuştur. Telefon kullanma sıklı̆̆1 orta düzeyde olan öğrencilerin bu davranışları üzerinde etkili olan değişkenin öğrencilerin cinsiyet durumları olduğu belirlenmiştir. Erkek öğrencilerin kız öğrencilere göre daha yüksek düzeyde bir dikkat kontrol mekanizmasına sahip olduğu bulunmuştur.

\section{2. İkinci Araştırma Sorusuna İlişkin Sonuçlar}

Bulgular incelendiğinde etki büyüklüğü en fazla olan değişkenin telefon kullanma sıklığı olduğu ve az olan değişkenin ise öğrencinin ebeveynleri ile yaşama durumu olduğu tespit edilmiştir. Bu sonuca göre öğrencilerin dikkat kontrollerini artırmak için öncelikli olarak telefon kullanımlarına yönelik tedbirlerin alınması ve ebeveynlerin de öğrenciye bu süreçte destek olması gerekir. Çünkü lise çağındaki öğrenciler için telefonun önemli bir yere sahip olduğu alanyazında belirtilmiştir. Doğal olarak öğrecinin telefon kullanımının sınırlandırılması beklenmedik bir etki oluşturabilir. Bu yüzden ebeveynlerin bu süreçte olumlu bir rol üstlenmeleri önemlidir. TÜBİTAK’ın “Gençler ve İletişim Teknolojileri” adlı projesinin sonuçları bu çalışmada elde edilen sonuçları desteklemektedir. TUBİTAK tarafindan yapılan projede genç bireylerin en sık kullandıkları elektronik cihazın telefon olduğu ve hayatlarından telefonu asla çıkartmayacaklarını belirtmişlerdir (TUBİTAK, 2010).

Yapılan çalışmanın sonuçları özetlendiğinde;

- Lise çağındaki öğrencilerin dikkat kontrolleri üzerinde etki düzeyi en yüksek değişkenin telefon kullanma sılklı̆̆ olduğu tespit edilmiştir.

- Lise öğrencilerinin telefon kullanma sıklığ1 üzerinde ise anne ve baba ile birlikte yaşama durumu, öğrencinin yaşı ve cinsiyet durumlarının etkili olduğu belirlenmiştir.

- CHAID analizinde değişkenler arasındaki ortak etki belirlendiğinden, anlamlı bulunan değişkenlerin ortak etkilerine bakılmış ve disordinal ortak etki olduğu bulunmuştur. 
$\mathrm{Bu}$ araştırmadan elde edilen sonuçlara dayalı olarak araştırmacılar ve uygulayıcılar için şu önerilerde bulunulmuştur.

- Lise çağındaki öğrencilerin fiziksel ve psikolojik gelişimlerinin devam etmesi ve bu araştırma kapsamında ulaşıldığı gibi dikkat kontrolü üzerinde etkili olması nedeniyle lise öğrencilerinin telefon kullanma sıklıklarını azaltmalarının yararlı olacağı düşünülmektedir.

- Lise öğrencilerinin dikkat kontrolleri üzerinde etkili olan diğer bir değişkenin öğrencinin ebeveyn ile birlikte yaşama durumu olduğu göz önüne alındığında ailelerin çocukları ile iyi ilişkiler geliştirmesinin önemli olduğu umulmaktadır.

- Dikkat kontrol mekanizmasında öğrencilerin yaşı anlamlı bir değissken olduğu göz önüne alındığında ilgili yaş gruplarındaki bu anlamlı farkın niçin oluştuğu araştırılabilir.

- Öğrencilerin cinsiyet durumuna göre dikkat kontrollerinin farklı olduğu göz önüne alındığında her iki cinsiyet grubu için yeniden bir çalışma yapılması önemli görünmektedir.

\section{KAYNAKÇA}

Abramson, M.J., Benke, P.G., Dimitriadis, C., Inyang, I.O., Sim, M.R. \& Wolfe, S.R. (2009). Mobiletelephone use is associated with changes in cognitive function in young adolescents. Bioelectromagnetics, 30(8), 678686.

Akın, A., Kaya, Ç., Uysal, R., Çardak, M., Çitemel, N., Özdemir, E., \& Gülşen, M. (2013). Dikkeat Kontrol Ölçeği Türkçe Formu: Geçerlik ve Güvenirlik Çalıs̆ması. VI. Ulusal Lisansüstü Eğitim Sempozyumu'nda sunulmuş bildiri.

Akkoyunlu, B., Altun, A., \& Yılmaz, M. (2011). Öğretim Tasarmı. Maya Akademi Yayınları, Ankara.

Brown, T. A. (2015). Confirmatory factor analysis for applied research. New York: Guilford Press.

Büyüköztürk, Ş. (2013). Sosyal bilimler için veri analiẓi el kitabı. Ankara: Pegem Akademi.

Büyüköztürk, Ş., Çakmak, E.K., Akgün, Ö.E., Karadeniz, Ş. ve Demirel, F. (2013). Bilimsel araşttrma yöntemleri. Ankara: Pegem Akademi.

Cammann R., \& Spiel, G. (1991) Neuropsychologische Grundlagen von Aufmerksamkeits- und Konzentrationsleistungen (Neuropsychological foundations of attention and concentration). In: Barchmann H, Kinze W, Roth N (eds) Aufmerksamkeit und Konzentration im Kindesalter. Berlin: Verlag Gesundheit, 11-26.

Cohen, J. (1988). Statistical Power Analysis for the Behavioral Sciences. NJ: Lawrence Erlbaum.

Çokluk, Ö., Şekercioğlu, G. \& Büyüköztürk, Ş. (2012). Sosyal bilimler için çok değģşkenli istatistik SPSS ve LISREL uygulamlar. Ankara: Pegem Akademi.

Demir, Y. M. (2009). Bilişsel bilgi işlem teorisi. M. Şahin (Ed.), Öğrenme teorileri (s. 130-182). Nobel, Ankara.

Deveci, S. E., Açık, Y., Gülbayrak, C., Demir, F., Karadă̆, M. \& Koçdemir, E. (2007). İlköğretim öğrencilerinin cep telefonu, bilgisayar, televizyon gibi elektromanyetik alan oluşturan cihazları kullanım s1klığ. Firat Tip Dergisi, 12(4), 279-283.

Diehl, M., Semegon, A. B., \& Schwarzer, R. (2006). Assessing attention control in goal pursuit: A component of dispositional self-regulation. Journal of Personality Assessment, 86(3), 306-317.

Ercan, İ., \& Kan, İ. (2004). Ölçeklerde güvenirlik geçerlik. Uludağ Üniversitesi T⿰р Fakültesi Dergisi, 30(3), 211 216.

Fajkowska, M. \& Derryberry, D. (2010) . Psychometric properties of Attentional Control Scale: The preliminary study on a Polish sample. Polish Psychological Bulletin, 41(1), 1-7.

Hair, J. F., Black, W. C., Babin, B. J., \& Anderson, R. E. (2010). Multivariate data analysis. New Jersey: Pearson Prentice Hall.

Hoare, R. (2004). Using CHAID For Classification Problems. New Zealand Statistical Association Conference'nda sunulmuş bildiri, New zealand.

İlhan, V. (2008). Yeni dünya düzeninde iletişim politikaları ve değişim: Cep telefonu kullanım alışkanlıkları ve tüketim yönelimleri. Erciyes Üniversitesi İletisim Fakültesi, 24(1), 293-316.

Karasar, N. (2014). Bilimsel Araştırma Yöntemi. Ankara: Nobel Yayıncıllk.

Kass, G.V. (1980). An exploraty tecnique for investigating large quantaties of categorical data. Applied Statistic, 29(2), 119-127.

Kayri, M. (2007). Araştırmalarda iki aşamalı kümeleme analizi ve bir uygulaması. Eurasian Journal of Educational Research, 28, 89-99.

Kirk, R. E. (2008). Statistics an introduction. Belmont: Thomson Higher Education. 
Küçük Doğaroğlu, T. (2013). Türkiye'de dikkat eksikliği ve hiperaktivite bozukluğu ile ilgili çalışmaların yürütüldügü lisansüstü tezlerin incelenmesi. Journal of Computer and Education Research, 1 (2), 90-112.

Luszczynska, A., Diehl M., Gutiérrez-Doña, B., Kuusinen P., \& Schwarzer, R. (2004). Measuring one component of dispositional self-regulation: Attention control in goal pursuit. Personality and Individual Differences, 37(3), 555-566.

Mathis, E. \& Bierman, K. (2012). Child Emotion Regulation and Attentional Control in Pre-Kindergarten: Associations with Parental Stress, Parenting Practices, and Parent-Child Interaction Quality. Society for Research on Educational Effectiveness, 1-9.

Özcebe, H., Aydın, M., Daştan, A. E., Fırat, E. \& Karaaslan, E. (2013). Bilişimde yeni bir alan: cep telefonlar ve gençler. İ. Sarı ve M. Özdemir (Ed.), Çoçuk ve Bilişim içinde (s. 342-368). Ankara: SAMER.

Öztürk, M. E., Bayraktar, G., Öztürk, D., \& Tozoğlu, E. (2016). Sağlık Hizmetleri Meslek Yüksekokulu Öğrencilerinin Dikkat Kontrol Düzeylerinin Spor ve Farklı Değişkinler Açısından Araştırılması. International Journal of Science Culture and Sport, 4(1), 76-83.

Pala, K. (2002). Cep telefonu baz istasyonlarının sağlı̆ga etkisi. Uludağ Üniversitesi Dergisi, 1, 41-43.

Pehlivan, G. (2006). CHAID analiæi ve bir uygulama. Yüksek Lisans Tezi, Yıldız Teknik Üniversitesi Fen Bilimleri Enstitüsü, İstanbul.

Prasad, S., Lim, V. K. G., \& Chen, D. J. Q. (2010). Self-regulation, individual characteristics and cyberloafing. Proceedings of the $14^{\text {th }}$ Pacific Asia Conference on Information Systems (PACIS), 1641-1648, Taipei, Taiwan.

Ratey, J. J. (2001). A User's Guide to the Brain. New York: Pantheon Books.

Ruf, B. \& Arthen, K. (2006). ADHS und wahrnebmungsauffaelligkeiten. Auer Verlag: Donauwörth.

Salthouse, T.A., Berish, D.E., \& Miles, J.D. (2002). The role of cognitive stimulation on the relations between age and cognitive functioning, Psychology and Aging, 17, 548-557.

Selçuk, Z. \& Öztürk, B. (1992). Öğrenme-Öğretme etkinliğini artırmada öğrenme stratejilerinin kullanılmas1; genel bir inceleme. Ë̆itim Dergisi, 1, 66-74.

Stanescu, D. F., \& Iorga, M. E. (2015). An exploratory study regarding the relations between time perspective, achievement motivation and self-regulation. Management Dynamics in the Knowledge Economy, 3(1), 7-24.

Sünbül, A. M. \& Çelik, M. (1998). Başarlı ve bașarısız ögrencilerin dikekat düzeylerinin karşılaștırlması. VII. Ulusal Eğitim Bilimleri Kongresi Bildirileri (ss.437-447). Konya: Selçuk Üniversitesi Eğitim Fakültesi.

TUBITTAK. (2010). Gençler ve İletișim Teknolojileri: TUBITTAK.

Üngüren, E., \& Doğan, H. (2010). Beş ylldızlı konaklama işletmelerinde çalışanların iş tatmin düzeylerinin CHAID analiz yöntemiyle değerlendirilmesi. Cumburiyet Üniversitesi İktisadi ve İdari Bilimler Dergisi, 11(2), $39-52$.

World Health Organization. (2002). Establishing a dialogue on risks from electromagnetic fields: World Health Organization.

Yayc1, L. (2007). İlköğretim Dördüncü Sinıf Öğrencilerinde Seçici ve Yoğunlașterlmıș Dikekat Becerilerini Geliștirmeye Dayalı Bir Programın Etkililiginin Sınanması. Doktora Tezi. T.C Marmara Üniversitesi Eğitim Bilimleri Enstitüsü İstanbul.

\section{Citation Information}

Şata, M. (2017). Lise öğrencilerinin dikkat kontrolleri üzerinde etkili olan değişkenlerin CHAID analizi ile incelenmesi. Dicle Üniversitesi Ziya Gökalp Eğitim Fakültesi Dergisi, 30, 465-475. 